\title{
PENATAAN PERPUSTAKAAN DESA UNTUK MENINGKATKAN LITERASI MEMBACA
}

\section{Ni Kadek Cintya Dewi ${ }^{1}$, Ni Wayan Rustiarini ${ }^{1}$}

\begin{tabular}{ll}
\hline Keywords : & Abstrak. Literasi menjadi komponen utama dalam \\
Literasi, & pengembangan sumber daya manusia. Meskipun demikian, \\
Membaca, & masyarakat Indonesia memiliki literasi yang sangat rendah. \\
Perpustakaan desa. & Hasil kajian menunjukkan bahwa jumlah perpustakaan \\
& desamasih sangat kurang. Selain itu, sarana dan prasarana \\
${ }^{*}$ Correspondensi Author & bacaan yang disediakan di perpustakaan desa juga masih \\
${ }^{1}$ Fakultas Ekonomi, Universitas & terbatas. Kegiatan pengabdian masyarakat ini bertujuan \\
Mahasaraswati Denpasar & untuk membenahi pengelolaan perpustakaan Desa Dangin \\
Jl. Kamboja No. 11A Denpasar-Bali & Puri Kelod sebagai upaya meningkatkan budaya literasi \\
Email: rusti_arini@unmas.ac.id & dalam masyarakat. Metode yang digunakan adalah \\
& partisipasi yang melibatkan peran serta aktif aparatur \\
& pemerintah desa, civitas akademika, dan masyarakat. \\
& Tahapan kegiatan pengabdian yang dilakukan adalah \\
& melakukan observasi, diskusi, pelaksanaan, dan sosialisasi. \\
& Adapun hasil kegiatan penataan perpustakaan desa telah \\
& terlaksana sesuai dengan rencana dan target yang \\
& ditetapkan, seperti menambah koleksi buku, melakukan \\
& inventarisasi, klasifikasi, dan administrasi perpustakaan. \\
& Dengan demikian, keberadaan perpustakaan desa \\
& diharapkan dapat meningkatkan literasi membaca \\
& masyarakat desa. \\
\hline
\end{tabular}

(1) This work is licensed under a Creative Commons Attribution

4.0 International License

\section{Pendahuluan}

Literasi menjadi komponen utama dalam pengembangan sumber daya manusia. Kata literasi berasal dari "literacy" yang berarti melek huruf, mampu baca tulis, cakap baca tulis (Bybee $\&$ McCrae, 2011; Ristanto et al., 2017). Mengacu pada pandangan ideologis kewacanaan, literasi adalah ketrampilan individu yang dituangkan dalam cara berpikir, berkomunikasi lisan (berbicara) dan tulisan (menulis), serta membaca (Gee, 2015). Menurut Stripling (1992), "literacy means being able to understand new ideas well enaugh to use them when needed. Literacy means knowing how to learn". Bertitiktolak dari definisi tersebut, literasi merupakan upaya untuk mencari, memahami, dan memiliki pengetahuan atau informasi.
Para ahli mendukung anggapan bahwa membaca merupakan salah satu sarana pendidikan informal individu serta memberikan pengalaman kepada masyarakat secara luas (Gorzycki et al., 2020). Dalam ranah akademis, membaca merupakan strategi untuk mengintegrasikan berbagai disiplin ilmu dalam pengetahuan pembaca sehingga meningkatkan keahlian dan ketrampilan pembaca (Berry et al., 2010; Moi, 2011). Literasi sekaligus menjadi cara ampuh untuk meningkatkan peradaban suatu bangsa. Tidak dapat dipungkiri bahwa kemajuan budaya suatu bangsa sangat ditentukan oleh karya-karya para cendekiawan, salah satunya diabadikan dalam bentuk tulisan. Semakin banyak karya yang dihasilkan, semakin banyak informasi yang diperoleh untuk membangun 
peradaban masyarakat di negara tersebut (Kusmana, 2017; Permatasari, 2015).

Meskipun literasi memiliki peran penting dalam pembangunan kualitas suatu bangsa, namun, masyarakat Indonesia memiliki literasi yang sangat rendah. Hasil kajian UNESCO menyebutkan bahwa minat baca masyarakat Indonesia hanya sebesar 0,001 persen. Angka ini mencerminkan bahwa pada 1000 orang masyarakat Indonesia, hanya terdapat satu orang yang gemar membaca. Selain itu, hasil survey juga menunjukkan bahwa rata-rata banyaknya buku yang dibaca per tahun oleh masyarakat Indonesia adalah sebanyak nol sampai satu buku (Permatasari, 2015). Apabila dibandingkan dengan tingkat literasi dunia, angka ini menunjukkan kondisi yang sangat memprihatinkan. Riset lainnya yang dilakukan oleh Central Connecticut State Univesity pada tahun 2016 juga menunjukkan bahwa minat membaca masyarakat Indonesia menduduki posisi nomor dua dari bawah, yaitu peringkat 60 dari 61 negara (Kominfo.go.id, 2017). Salah satu faktor yang menyebabkan rendahnya tingkat literasi masyarakat adalah perbedaan rasio ketersediaan bacaan dan jumlah penduduk yang sangat jauh. Tidak dapat dipungkiri bahwa ketersediaan akses informasi merupakan faktor penting untuk meningkatkan aktivitas literasi (Miller \& McKenna, 2016).

Demikian pula halnya dengan kajian yang dilakukan oleh Pusat Penelitian Kebijakan Pendidikan dan Kebudayaan pada 34 provinsi di Indonesia. Hasil perhitungan untuk Indeks Aktivitas Literasi Membaca (Alibaca) secara nasional masuk kriteria "aktivitas literasi rendah" (Puslitjakdikbud, 2019). Indeks ini mencakup empat dimensi, yaitu dimensi kecakapan, dimensi akses, dimensi alternatif, dan dimensi budaya. Hasil kajian untuk Indeks Alibaca disajikan pada Gambar 1.

Hasil kajian ini sekaligus menyajikan informasi bahwa apabila dibandingkan dengan jumlah desa yang ada, jumlah perpustakaan desa masih sangat kurang. Jumlah perpustakaan dikatakan ideal apabila dalam setiap jenjang pemerintahan memiliki minimal satu perpustakaan (Puslitjakdikbud, 2019). Berdasarkan kajian tersebut, pemerintah Indonesia gencar untuk melakukan upaya peningkatan literasi membaca melalui pembangunan perpustakaan desa.

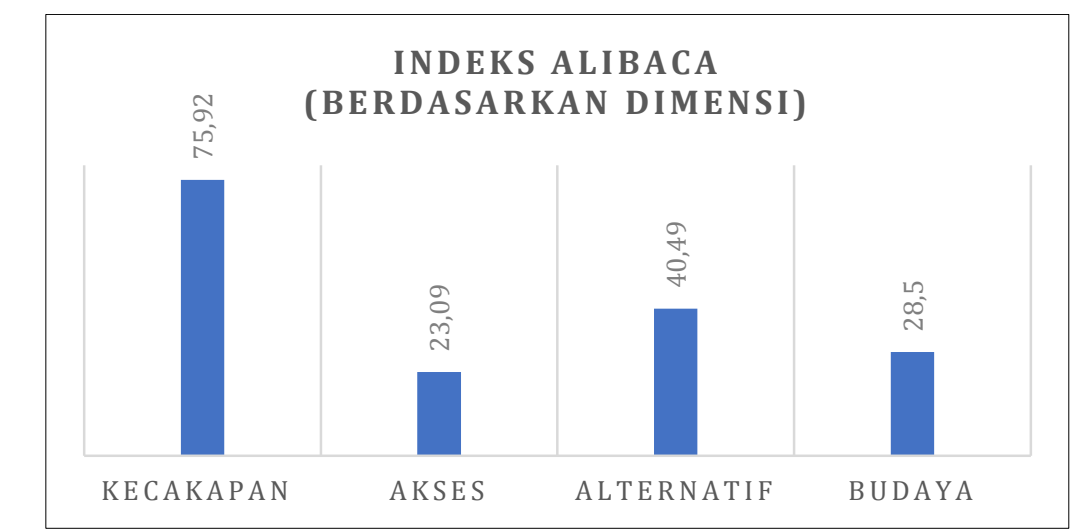

Sumber: Pusat Penelitian Kebijakan Pendidikan dan Kebudayaan (2019)

\section{Gambar 1. Indeks Aktivitas Literasi Membaca (Alibaca) Nasional}

Ketentuan ini juga menyatakan bahwa perpustakaan tidak hanya sebagai wahana pendidikan, namun juga sebagai wahana penelitian, pelestarian, informasi, dan rekreasi. Bertitiktolak dari regulasi ini, keberadaan perpustakaan tidak hanya diperlukan dalam dunia pendidikan namun juga berperan penting dalam mendukung pengembangan sumber daya manusia di pedesaan. Saat ini, perpustakaan desa telah bertransformasi menjadi pusat informasi pengembangan diri (Maskurotunitsa \&
Rohmiyati, 2016), sarana pendidikan informal (Alam, 2015), serta fasilitator kebutuhan masyarakat desa (Berdesa.com, 2018). Meskipun demikian, pembangunan perpustakaan desa bukanlah pekerjaan yang mudah. Terdapat beberapa kondisi yang harus dipenuhi agar perpustakaan desa dapat memberikan manfaat yang maksimal kepada masyarakat. Dalam hal ini, pemerintah desa berkewajiban untuk merealisasikan keberadaan perpustakaan desa sehingga meningkatkan literasi masyarakat. 
Berdasarkan fenomena tersebut, kegiatan pengabdian yang dilakukan di Desa Dangin Puri Kelod berkaitan dengan penataan perpustakaan desa. Berdasarkan hasil observasi dan wawancara dengan aparatur pemerintah desa, terdapat beberapa permasalahan yang menjadi prioritas, seperti 1) keterbatasan ruangan perpustakaan sehingga membatasi jumlah masyarakat yang hendak berkunjung; 2) buku-buku masih ditumpuk pada sudut ruangan tertentu dan jumlah buku masih terbatas; 3) belum melakukan inventarisasi jumlah dan jenis buku sehingga sulit untuk mendata buku-buku bacaan yang tersedia di perpustakaan desa. Kegiatan pengabdian masyarakat ini merupakan salah satu bentuk kerjasama Universitas Mahasaraswati Denpasar dan Desa Dangin Puri Kelod yang direalisasikan dalam bentuk Kuliah Kerja Nyata.

Adapun tujuan kegiatan pengabdian ini adalah untuk menata pengelolaan perpustakaan desa sebagai upaya meningkatkan budaya literasi masyarakat desa. Peningkatan literasi membaca tidak hanya dapat meningkatkan kreativitas dan daya saing masyarakat namun juga meningkatkan pemahaman masyarakat akan realitas kehidupan. Selain itu, peningkatan literasi juga diharapkan mengarahkan masyarakat untuk memperbaiki taraf hidup masyarakat. Oleh karena itu, kehadiran perpustakaan desa diharapkan dapat meningkatkan literasi dan budaya membaca, bahkan menjadikan sebagai gaya hidup masyarakat Indonesia.

\section{Metode}

Kegiatan pengabdian ini dilakukan di pemerintah Desa Dangin Puri Kelod, Kecamatan Denpasar Timur, Kotamadya Denpasar, Propinsi Bali. Kegiatan pengabdian ini dikemas dalam Kuliah Kerja Nyata yang dilaksanakan secara efektif selama dua bulan. Pelaksanaan kegiatan meliputi metode partisipasi yang melibatkan peran serta aktif aparatur pemerintah desa, civitas akademika, dan masyarakat. Target umum kegiatan pengabdian masyarakat ini adalah untuk meningkatkan literasi membaca masyarakat desa. Target khususnya adalah melakukan penguatan fasilitas perpustakaan desa.

Tahapan-tahapan kegiatan pengabdian adalah sebagai berikut. Pertama, melakukan observasi untuk mengidentifikasi permasalahanpermasalahan yang dialami pemerintah desa terkait dengan pengelolaan perpustakaan desa. Kedua, melakukan wawancara dan diskusi untuk menetapkan permasalahan yang menjadi prioritas, serta membahas rencana kegiatan pengabdian yang akan dilakukan untuk mengatasi permasalahan tersebut. Ketiga, merupakan tahap inti pengabdian, yaitu melaksanakan penataan perpustakaan desa dengan melibatkan para aparatur pemerintah desa. Tahap terakhir merupakan tahap sosialisasi kehadiran perpustakaan desa kepada masyarakat desa. Tahapan kegiatan pengabdian disajikan pada Gambar 2.

\section{Hasil dan Pembahasan}

Rendahnya tingkat literasi membaca masyarakat mencerminkan kualitas sumber daya manusia Indonesia. Fakta ini tidak hanya menjadi tanggung jawab pemerintah pusat namun juga perlu mendapatkan perhatian dari seluruh level pemerintahan, termasuk pemerintah desa. Meskipun demikian, upaya peningkatan literasi membaca bukanlah perkara mudah. Masyarakat harus mendapatkan fasilitas yang mampu mengakomodasikan kebutuhan dan keinginan masyarakat untuk membaca (Maulida, 2016). Menurut Fuad Hasan, terdapat tiga komponen yang harus dipenuhi untuk menumbuhkan budaya baca masyarakat, yaitu 1) kemampuan membaca, 2) ketersediaan bahan bacaan, dan 3) membina atau menumbuhkan kebiasaan membaca (Sutarno, 2003). Mengingat ketiga komponen ini memiliki arti penting yang sama, kegagalan dalam memenuhi salah satu kriteria tersebut akan menyulitkan pemerintah untuk mewujudkan budaya gemar membaca. Hubungan komponen tersebut disajikan pada Gambar 3.
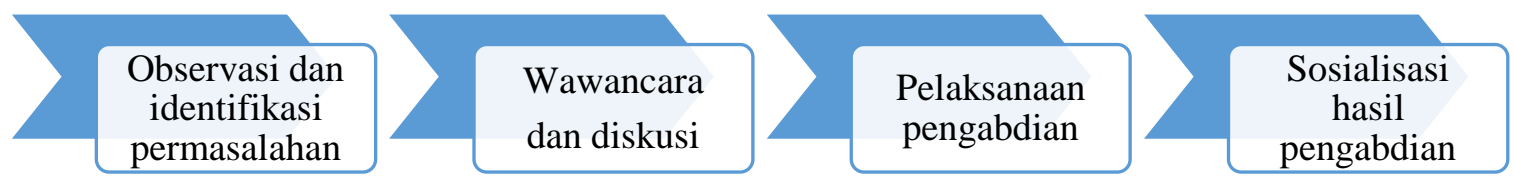

Gambar 2. Tahapan-tahapan Kegiatan Pengabdian

Miller dan McKenna (2016) menyampaikan bahwa upaya peningkatan literasi membaca masyarakat dapat ditingkatkan melalui interaksi empat komponen, yaitu: 
Ni Kadek Cintya Dewi, Ni Wayan Rustiarini. Penataan Perpustakaan Desa untuk Meningkatkan Literasi Membaca

1. Proficiency (kecakapan), merupakan kriteria awal agar seseorang dapat mengakses sumber informasi, seperti masyarakat terbebas dari buta aksara.

2. Access (akses), merupakan ketersediaan sumber daya pendukung agar masyarakat dapat mengakses atau memanfaatkan sumber informasi, seperti perpustakaan, toko buku, atau media massa.
3. Alternative (pilihan), merupakan ketersediaan pilihan perangkat teknologi yang beragam untuk dapat mengakses sumber informasi.

4. Culture (budaya), merupakan upaya untuk membentuk atau menumbuhkan budaya literasi. Budaya ini dibentuk dari lingkungan keluarga, sekolah, maupun komunitas lain yang lebih luas. Interaksi keempat komponen tersebut disajikan pada Gambar 4.

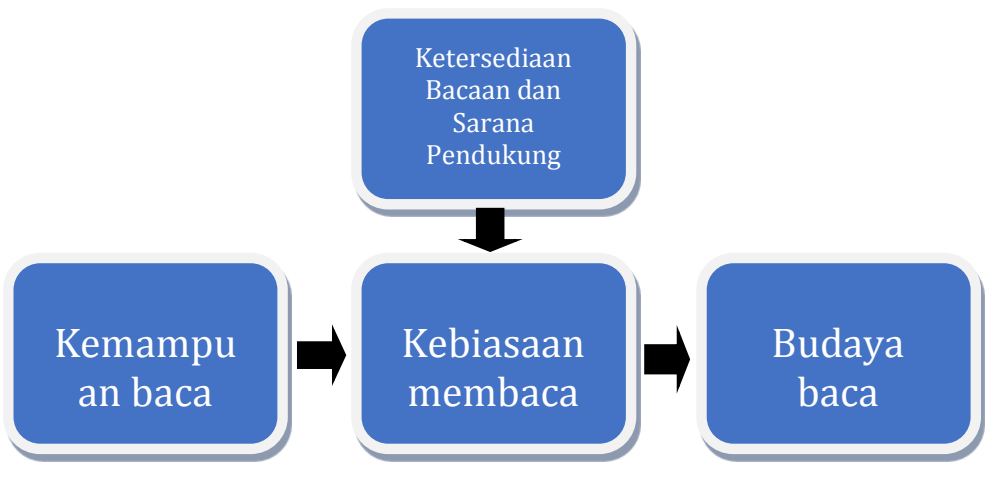

Sumber: Fuad Hasan (dalam Sutarno, 2003)

Gambar 3. Upaya Menumbuhkan Budaya Membaca

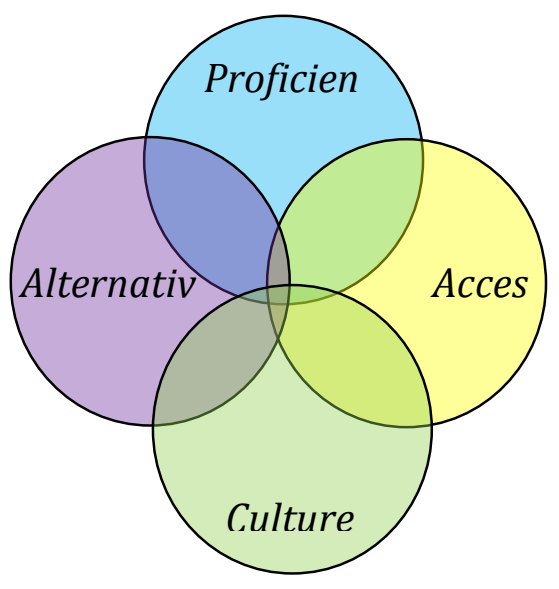

Sumber: Miller dan McKenna (2016)

\section{Gambar 4. Interaksi Komponen untuk Meningkatkan Literasi Membaca}

Mengacu pada Undang-undang No 6 Tahun 2014, pemerintah desa memiliki kewenangan untuk melakukan pembangunan desa, salah satunya melalui perbaikan sarana prasarana desa. Pembangunan desa tidak hanya bertujuan untuk mengangkat kesejahteraan masyarakat namun juga untuk mengurangi kesenjangan ekonomi dan pembangunan masyarakat di desa dan kota (Kurniawan et al., 2020). Agar proses pembangunan desa dapat terlaksana secara efektif, pemerintah desa perlu memfasilitasi akses informasi atau pengetahuan ke desa dengan cara membangun perpustakaan desa. Perpustakaan desa memiliki peran penting dalam upaya pengentasan buta huruf, khususnya bagi masyarakat desa. Selain menjadi agen pendidikan non formal, perpustakaan desa juga menjadi agen pembangunan atau perubahan bagi masyarakat desa (Hermanto, 2015). Oleh karena itu, dalam upaya mewujudkan peran 
perpustakaan desa sebagai penyedia informasi, pengelolaan perpustakaan desa harus melibatkan aparatur desa selaku penyelenggara perpustakaan desa dan masyarakat lokal selaku pengguna (Sukoco \& Winarni, 2018).

Perpustakaan desa dapat dikategorikan sebagai perpustakaan umum yang didirikan di setiap desa atau kelurahan. Keberadaan perpustakaan desa memiliki legalitas yang dituangkan dalam Surat Keputusan Menteri Dalam Negeri Nomor 3 Tahun 2001 Tentang Perpustakaan Desa/Kelurahan. Dengan demikian, dapat disimpulkan bahwa perpustakaan desa menjadi bagian integral atau kesatuan dari kegiatan pembangunan yang dilakukan di wilayah desa atau kelurahan (Darmono, 2016). Mengacu pada regulasi tersebut, ada empat poin utama dalam memaknai perpustakaan desa. Pertama, pengelolaan perpustakaan dilakukan dengan berbasis kebutuhan masyarakat. Kedua, perpustakaan harus berfungsi sebagai media atau sarana untuk proses pembelajaran. Ketiga, perpustakaan berperan untuk mendukung dan meningkatkan aktivitas pendidikan masyarakat. Terakhir, keberadaan perpustakaan desa merupakan bagian integral pembangunan, khususnya pembangunan desa (Darmono, 2016).

Dalam kegiatan pengabdian ini, pelaksanaan kegiatan penataan perpustakaan desa dilakukan secara bersama-sama oleh aparatur pemerintah desa dan civitas akademika. Kegiatan ini diawali dengan sosialisasi atau penyuluhan tentang tata cara penataan buku dan pengelolaan perpustakaan desa yang diberikan

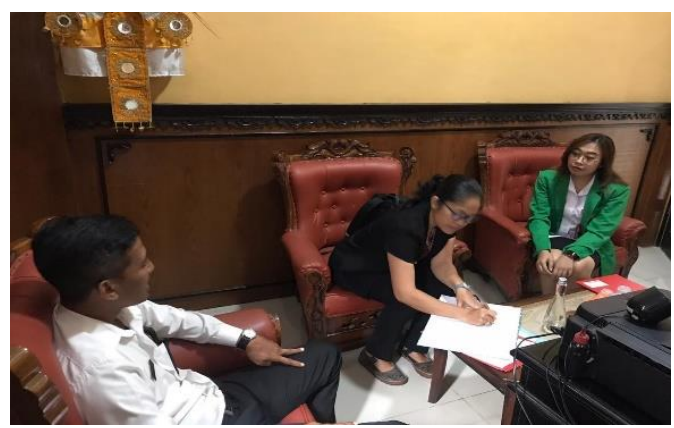

Gambar 5. Melakukan diskusi terkait permasalahan perpustakaan desa oleh Dinas Perpustakaan dan Kearsipan Kota Denpasar. Kegiatan selanjutnya adalah pembuatan profil perpustakaan desa Dangin Puri Kelod yang bernama "Vidyanata Pustaka". Pembuatan profil perpustakaan desa memuat identitas, tugas dan fungsi, serta sumber pendanaan, dan sumber daya perpustakaan. Kegiatan yang dilakukan disajikan pada Gambar 5 dan 6.

Selanjutnya, pemerintah desa melakukan pengadaan koleksi buku-buku bacaan sesuai dengan kebutuhan masyarakat. Pengadaan koleksi buku didasarkan atas kebutuhan pemberdayaan masyarakat dan upaya pengembangan diri masyarakat. Kecukupan bahan bacaan merupakan syarat utama yang harus dipenuhi agar perpustakaan desa dapat berfungsi secara maksimal. Salah satu upaya untuk memenuhi kecukupan bahan bacaan adalah dengan cara memanfaatkan buku-buku yang telah tersedia sebelumnya namun belum tertata dalam rak buku. Oleh karena itu, civitas akademika bersama-sama dengan aparatur pemerintah desa membersihkan buku-buku lama yang ditumpuk di sudut ruangan. Aktivitas selanjutnya adalah melakukan inventarisasi buku-buku bacaan yang berjumlah 573 buku. Tahap selanjutnya adalah mengelompokkan buku sesuai dengan kategori, yaitu kategori umum sebanyak 32 buku, kategori filsafat sebanyak 53 buku, kategori agama sebanyak 42 buku, kategori sosial sebanyak 247 buku, kategori bahasa sebanyak 5 buku, kategori teknologi sebanyak 67 buku, kategori seni sebanyak 83, dan kategori sains dan matematika sebanyak 44 buku, sebagaimana ditunjukkan pada Gambar 7 dan 8 .

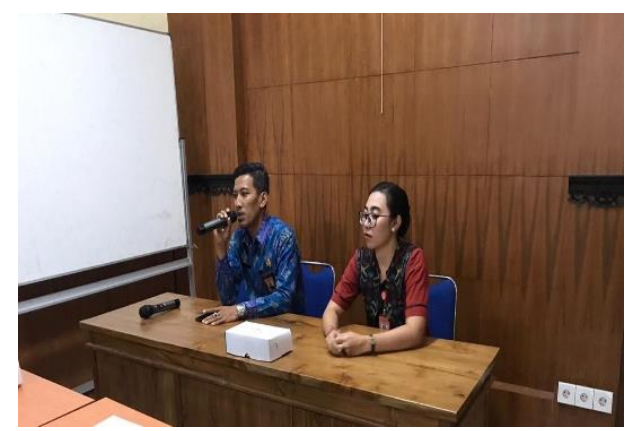

Gambar 6. Sosialisasi mengenai pengelolaan perpustakaan desa 


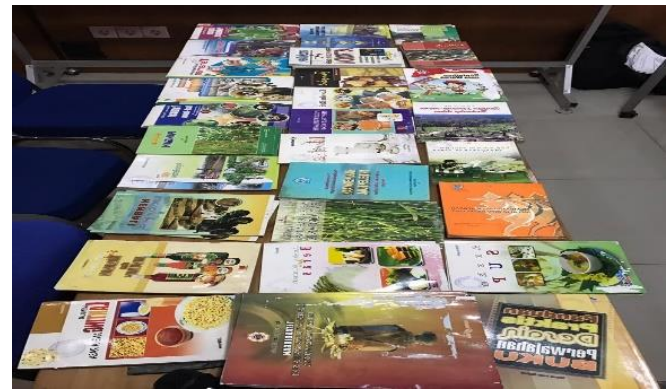

Gambar 7. Pengadaan koleksi buku-buku bacaan

Aktivitas selanjutnya adalah melakukan penataan administrasi perpustakaan, seperti katalogisasi dan pengecapan. Tahap terakhir adalah melakukan penataan buku-buku bacaan sesuai dengan klasifikasinya. Hal ini bertujuan untuk memudahkan masyarakat mencari buku bacaan yang sesuai dengan minat mereka. Aktivitas pengabdian ini disajikan pada Gambar 9 dan 10.

Tahap terakhir adalah melakukan sosialisasi mengenai fasilitas perpustakaan desa. Upaya ini untuk mempromosikan kehadiran perpustakaan sehingga dapat meningkatkan minat masyarakat untuk berkunjung. Meskipun demikian, hasil evaluasi mengungkapkan salah satu tantangan dalam meningkatkan literasi membaca masyarakat saat ini adalah hadirnya teknologi informasi. Di satu sisi, penguasaan teknologi informasi yang tepat dapat membantu masyarakat untuk mendapatkan informasi dan pengetahuan secara cepat dan mudah. Di sisi lain, keberadaaan teknologi justru menimbulkan anggapan bahwa membaca merupakan aktivitas yang membosankan (Suragangga, 2017). Generasi muda umumnya memilih informasi yang bersifat visual sehingga fenomena ini justru mengurangi keinginan masyarakat untuk membaca buku. Oleh karena itu, berdasarkan hasil evaluasi kegiatan yang dilakukan, pemerintah desa harus senantiasa melakukan

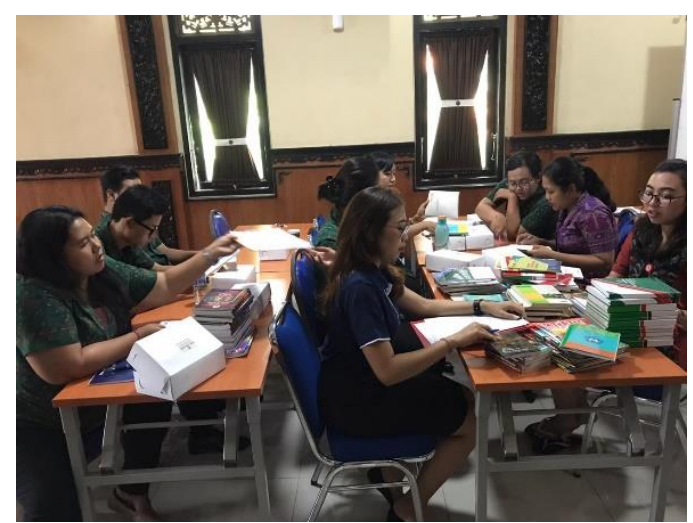

Gambar 9. Melakukan klasifikasi dan pengecapan

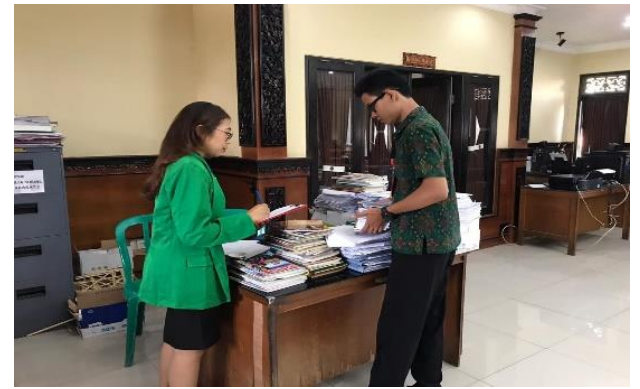

Gambar 8. Melakukan inventarisasi dan penghitungan buku

sosialisasi keberadaan perpustakaan desa dalam setiap kegiatan desa.

\section{Simpulan dan Saran}

Secara umum dapat disimpulkan bahwa kegiatan penataan perpustakaan desa telah terlaksana sesuai dengan rencana dan target yang ditetapkan, seperti menambah koleksi buku, melakukan inventarisasi, klasifikasi, dan administrasi perpustakaan. Adapun rekomendasi yang bisa diberikan dalam kegiatan ini adalah agar aparatur pemerintah desa senantiasa mempromosikan keberadaan perpustakaan desa dalam setiap kegiatan masyarakat. Hal ini dilakukan agar perpustakaan desa dapat berperan untuk meningkatkan literasi membaca masyarakat desa. Agar fungsi perpustakaan desa dapat berkelanjutan, perangkat desa hendaknya menugaskan salah satu staf pemerintah desa untuk mengelola perpustakaan desa secara profesional. Selain itu, di masa mendatang, para aparatur desa hendaknya dapat mentransformasikan perpustakaan desa konvensional menjadi perpustakaan berbasis digital (online). Dengan demikian, perpustakaan dapat menjangkau masyarakat secara lebih luas, tanpa dibatasi tempat dan waktu

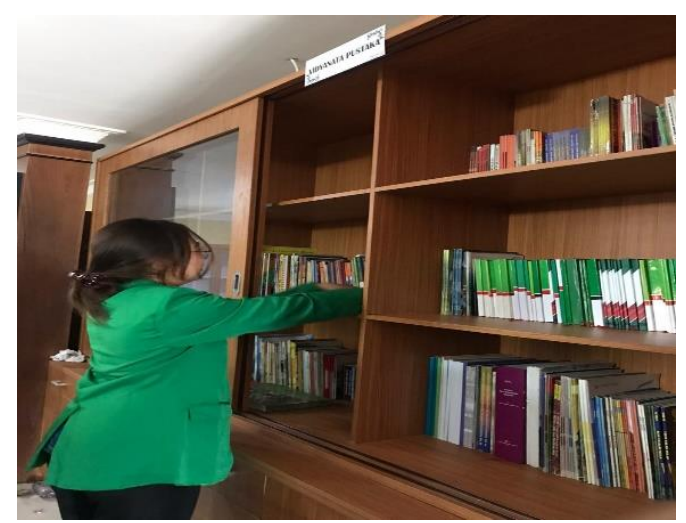

Gambar 10. Melakukan penyusunan koleksi buku-buku bacaan 
Ni Kadek Cintya Dewi, Ni Wayan Rustiarini. Penataan Perpustakaan Desa untuk Meningkatkan Literasi Membaca

\section{Daftar Rujukan}

Alam, S. (2015). Membangun perpustakaan desa menjadi peletak dasar lahirnya budaya baca masyarakat di pedesaan. Jupiter, $X I V(2), 78-82$.

Berdesa.com. (2018). Sepenting Apakah Perpustakaan Bagi Desa? http://www.berdesa.com/sepentingapakah-perpustakaan-bagi-desa/

Berry, T., Cook, L., Hill, N., \& Stevens, K. (2010). An exploratory analysis of textbook usage and study habits: Misperceptions and barriers to success. College Teaching, 59(1), 31-39. https://doi.org/10.1080/87567555.2010.50 9376

Bybee, R., \& McCrae, B. (2011). Scientific literacy and student attitudes: Perspectives from PISA 2006 science. International Journal of Science Education, 33(1), 7-26. https://doi.org/10.1080/09500693.2010.51 8644

Darmono. (2016). Manajemen Pelayanan Perpustakaan Desa. Kegiatan Koordinasi Pengembangan Budaya Baca-Bimtek Kader Pustaka Se-Kabupaten Malang. http://lib.um.ac.id/wpcontent/uploads/2017/03/MakalahManajemen-Pelayanan-PerpustakaanDesa.pdf

Gee, J. (2015). Social Linguistics and Literacies: Ideology in Discourses. Routledge.

Gorzycki, M., Desa, G., Howard, P. J., \& Allen, D. D. (2020). "Reading is important," but "I don't read": Undergraduates' experiences with academic reading. Journal of Adolescent \& Adult Literacy, 63(5), 499-508. https://doi.org/10.1002/jaal.1020

Hermanto, B. (2015). Optimalisasi perpustakaan desa dalam rangka meningkatkan pendidikan masyarakat. Jurnal Pustaka Ilmiah, 1(1), 71-76.

Kominfo.go.id. (2017). Teknologi Masyarakat Indonesia: Malas Baca Tapi Cerewet di Medsos. https://www.kominfo.go.id/content/detail/1 0862/teknologi-masyarakat-indonesiamalas-baca-tapi-cerewet-dimedsos/0/sorotan_media

Kurniawan, I., Setiawan, B., \& Listiani, T. (2020). Pembinaan aparatur pemerintah desa dalam bidang manajemen pemerintahan desa bagi para kepala desa dan perangkat desa di Kecamatan Cikajang Kabupaten Garut. LOSARI: Jurnal Pengabdian Kepada Masyarakat, 2(2), 32 36.

Kusmana, S. (2017). Pengembangan literasi dalam kurikulum pendidikan dasar dan menengah. Diglosia: Jurnal Pendidikan, Kebahasaan, Dan Kesusastraan Indonesia, 1(1), 140-150.

Maskurotunitsa, R. S., \& Rohmiyati, Y. (2016). Peran perpustakaan desa "Mutiara" dalam pemberdayaan masyarakat Desa Kalisidi Kecamatan Ungaran Barat Kabupaten Semarang. Jurnal Ilmu Perpustakaan, 5(4), 81-90.

Maulida, H. N. (2016). Peran perpustakaan daerah dalam pengembangan minat baca di masyarakat. IQRA: Jurnal Ilmu Perpustakaan Dan Informasi, 9(2), 235251.

Miller, J. W., \& McKenna, M. M. (2016). World Literacy: How Countries Rank and Why It Matters. Routledge.

Moi, T. (2011). The adventure of reading: Literature and philosophy, Cavell and Beauvoir. Literature and Theology, 25(2), 125-140. https://doi.org/10.1093/litthe/frr014

Permatasari, A. (2015). Membangun kualitas bangsa dengan budaya literasi. Prosiding Seminar Nasional Bulan Bahasa UNIB 2015.

Puslitjakdikbud. (2019). Indeks Aktivitas Literasi Membaca. http://repositori.kemdikbud.go.id/13033/1/ Puslitjakdikbud_Indeks Aktivitas Literasi Membaca 34 Provinsi

Ristanto, R. H., Zubaidah, S., Amin, M., \& Rohman, F. (2017). Scientific literacy of students learned through guided inquiry. International Journal of Research \& Review, 4(5), 23-30.

Stripling, B. K. (1992). Libraries for The National Education Goals. Eric Clearinghouse on Information.

Sukoco, J. B., \& Winarni, L. (2018). Administrasi pengelolaan perpustakaan di Desa Puro Kabupaten Sragen. Journal of Public Administration and Local Governance, 2(2), 60-79.

Suragangga, I. M. N. (2017). Mendidik lewat literasi untuk pendidikan berkualitas. Jurnal Penjaminan Mutu, 3(2), 154-163. 
Ni Kadek Cintya Dewi, Ni Wayan Rustiarini. Penataan Perpustakaan Desa untuk Meningkatkan Literasi Membaca

Surat Keputusan Menteri Dalam Negeri Nomor

3 Tahun 2001 tentang Perpustakaan

Desa/Kelurahan, (2001).
Sutarno, N. . (2003). Perpustakaan dan Masyarakat. Yayasan Obor Indonesia. 